\title{
Asian management in the 21st century
}

\author{
Geert Hofstede
}

Published online: 16 May 2007

(C) Springer Science + Business Media, LLC 2007

\begin{abstract}
Contrary to popular opinion, the crucial elements of the management process show strong continuity over time, but differ from one country to another, as a function of the local culture. Recent research reveals fundamental differences in the goals of business leaders from different societies. The article explores general characteristics of Asian management as opposed to management elsewhere, and what the study of Asian management and its cultural origins mean for the emerging Asian multinationals and for the state of the art in management research worldwide in the twenty-first century.
\end{abstract}

Keywords Asian management

\section{About Europeans and Asians}

As a contributor to the first two volumes of the Asia Pacific Journal of Management (Hofstede, 1984a, 1984b), I was asked to write something for the Journal's 25th Anniversary Special Issue. I do this as a European, a visitor from the other side of the same continent. Unlike our American or even our Japanese colleagues, I don't need an airplane or a boat to get to Asia. From my home in Holland, I can get to Hong Kong by train - it is true, my wife and I once did it. This raises the question: if we call Hong Kong East Asia, why not call Holland West Asia?

The distinction between Asia and Europe is historical rather than geographical. It relates to the origin of the name Asia. The word has come a long way: we owe it to the Phoenician sailors who 3,000 years ago lived in the present Lebanon and who

The author thanks Mike Peng (Editor-in-Chief) for his invitation and editorial suggestions.

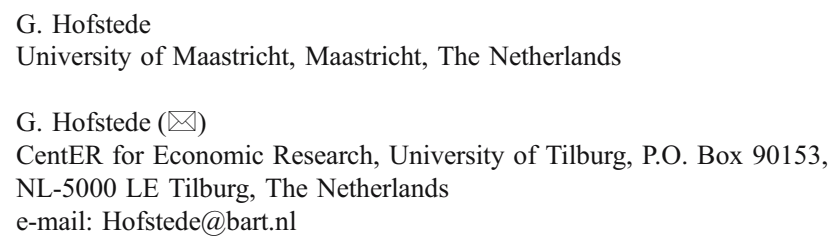


spoke a Semitic language related to present-day Arabic and Hebrew. The Phoenicians at sea oriented themselves between esch and ereb, that is dawn and dusk, or East and West; and this became Asia and Europa. Greek mythology then turned Asia and Europa into goddesses. Europa was a beautiful girl who was abducted by their senior god Zeus, who for the occasion had disguised himself as a bull. Asia was either the wife or the mother of the titan Prometheus. Prometheus was a mythical hero who managed to steal the fire from the gods and gave it to mankind, enabling man to develop civilization and prosperity. So even in those old days the name Asia was already associated with these desirable ends.

The Greeks also took the geographical distinction from the Phoenicians: Asia was everything East of them, the present Turkey and beyond, and Europe everything West of them, already in the fifth century B.C. Their distinction was inherited by the Romans and subsequently by all Europeans who when they went out to discover the world extended the name "Asia" to any land they found East of Turkey, all the way to Indonesia and Japan. ${ }^{1}$

\section{The continuity of management problems over time}

The founding of an Asia Pacific Journal of Management (1983), and later of an Asia Academy of Management (1998), raises the question to what extent management is determined by geography: Is there an "Asian management" distinct from management elsewhere? When the Academy was founded in 1998, a more common question was to what extent management is determined by time: What would be new about management in the twenty-first century? Most of the popular management literature implicitly assumes that management problems change over time-one should always follow the latest trends - but that they are universal across the world: managing means the same anywhere, whether in North America, France, Brazil, Russia, Thailand, or China. If Western management principles don't work somewhere, this is not the fault of the principles but of the people.

Against these alleged assumptions in the popular management press, I would like to defend the opposite viewpoint: "That management problems basically have remained and will remain the same over time, and that their solutions differ less from period to period than from part of the world to part of the world, and even from country to country."2

What is management? I prefer a general definition: getting things done through other people. Or more specifically: coordinating the efforts of people towards common goals. The other people involved may be subordinates, clients, customers, suppliers, authorities, or the public in general. Important is that management is always about people. Jobs in which no other people are involved are technical, not management.

\footnotetext{
${ }^{1}$ This part is borrowed from my unpublished Keynote Speech at the Inaugural Conference of the Asia Academy of Management, Hong Kong, December 28, 1998.

${ }^{2}$ For more extensive arguments for my case, see Hofstede (1999). 
Because management is always about people, it is part of the culture of the society in which it takes place. Culture is the collective programming of the mind which distinguishes the members of one group or category of people from another. The title of my first 1984 contribution to $A P J M$ was "Cultural dimensions in management and planning," and its Abstract starts with the sentence "The nature of management skills is such that they are culturally specific: a management technique or philosophy that is appropriate in one national culture is not necessarily appropriate in another" (Hofstede, 1984a: 81).

The core element in culture are values. Values are broad tendencies to prefer certain states of affairs over other. They are about what is evil and what is good, dirty and clean, immoral and moral, irrational and rational. Relationships between people in a society are always affected by the values which form part of the collective programming of people's minds in that society. So management is subject to cultural values. Cultural values differ among societies, but within a society they are remarkably stable over time. This is why I claim that management, which is part of culture, differs among societies but within societies is stable over time.

The historical continuity of the national component in management was convincingly demonstrated by the French anthropologist Philippe d'Iribarne (1989). He did in-depth interviews in three production plants of a French-owned aluminum company, one in France, one in the USA, and one in The Netherlands. The plants were technically identical, but interactions on the shop floor differed dramatically. D'Iribarne in his book identified three different philosophies that control the local management: honor in France, fair contract in the USA, and consensus in the Netherlands. These philosophies represent patterns of thinking distinguishable in the histories of these three societies for centuries. For France d'Iribarne referred to the Ancien Régime (the seventeenth and eighteenth century monarchy before Napoleon); for the USA to the heritage of the Pilgrim Fathers and other seventeenth and eighteenth century immigrants; for The Netherlands to the Dutch Republic of the seventeenth century.

But, you may object, the Pilgrim Fathers did not produce aluminum. Of course, the technical content of the management process changed completely, and it keeps changing today. Just think of the influence of electronic communication. However, I insist that values are resilient against technology. Technology affects culture in general and management in particular not on the basic level of values, but on the more superficial level of practices. Practices change according to the needs of the day and to the available resources, but they do not necessarily affect the underlying values. Practices depend on your computer programs, but the purposes to which these programs will be put depend on the values of the persons in front of the screen who are children of their culture.

Therefore, management in the twenty-first century is not basically different from management in the twentieth. In fact, similar management problems have existed as long as human societies have existed. Examples of management problems, even if they were not called that way, can be found all over the world literature, from the oldest sources onwards. American business professor Karl Moore and historian David Lewis (1999) have described the management of multinational businesses run by Assyrians, Phoenicians, Greeks, and Romans in the Mediterranean area between 1900 and 100 B.C.the problems they write about resemble those of modern globalizing companies. 


\section{Differences in management problems across countries}

To illustrate geographic differences in management, I will use two case studies, each based on a great work from the world literature. The management problem in both cases is the same: privatization of tasks. My first case is from China. Cao Xueqin's The Dream of the Red Chamber (Cao, 1980) was originally published around 1760. It describes the rise and fall of two branches of an aristocratic family in Beijing, who live in adjacent plots in the capital. Their plots are joined by a magnificent garden with several pavilions in it (now memorized in the Prospect Garden Park in Beijing), and the young, mostly female members of both families are allowed to live in them. One day the management of the garden is taken over by one of the young women, Tan Chun, who states:

"I think we ought to pick out a few experienced trustworthy old women from among the ones who work in the Garden-women who know something about gardening already - and put the upkeep of the Garden into their hands. We needn't ask them to pay us rent; all we need ask them for is an annual share of the produce. There would be four advantages in this arrangement. In the first place, if we have people whose sole occupation is to look after trees and flowers and so on, the condition of the Garden will improve gradually year after year and there will be no more of those long periods of neglect followed by bursts of feverish activity when things have been allowed to get out of hand. Secondly there won't be the spoiling and wastage we get at present. Thirdly the women themselves will gain a little extra to add to their incomes which will compensate them for the hard work they put in throughout the year. And fourthly, there's no reason why we shouldn't use the money we should otherwise have spent on nurserymen, rockery specialists, horticultural cleaners and so on for other purposes." (Cao, 1980 [1760], Vol. 3: 69)

As the story goes on, the capitalist privatization-because that is what it is - of the Garden is carried through, and it works. When in the 1980s Deng Xiaoping allowed privatization in the Chinese villages, it amazingly also worked. It worked so well that its effects started the present Chinese economic boom.

My second case is from Russia. Lev Nikolayevich Tolstoy's novel Anna Karenina was published in 1878. One of its main characters is a landowner, Levin, whom Tolstoy used to express his own views and convictions about his people. Until 1861 Russian peasants had been serfs tied to their lands and their lord. As serfs they had been passive, only doing as they were told. Levin wanted to break this passivity by dividing the land among his peasants in exchange for a share of the crops; but the peasants only let the land deteriorate further. Here follows a quote:

"(Levin) read political economy and socialistic works ... but, as he had expected, found nothing in them related to his undertaking. In the political economy books ... he found only certain laws deduced from the state of agriculture in Europe; but he could not for the life of him see why these laws, which did not apply to Russia, should be considered universal ... Socialist teaching told him that development along those lines leads to ruin. And neither of them offered the smallest enlightenment as to what he, Levin, and all the 
Russian peasants and landowners were to do with their millions of hands and millions of acres, to make them as productive as possible for the common good.” (Tolstoy, 1978 [1878]: 366-367)

Since the end of communism there have been years that the Russian lands produced a record crop, but that part of it rotted away because there were no hands to harvest it. Western experts have flocked into Russia to apply the same principles of political economy which Tolstoy already found lacking - and not surprisingly they failed again.

What works in China - and worked two centuries ago - does not have to work in Russia, neither in Tolstoy's days nor today. I am not offering a solution. I only protest against a naive universalism that knows only one recipe for managing economic development, consisting in the approach supposed to have worked in the authors' own country, usually the USA. Different societies in the world have different histories and they maintain different values: there is no one universal human values system. Moreover, different societies have different resources and meet different practical problems. Universal solutions to management problems do not exist; they would presuppose one universal type of human being in one universal type of society. But in history the rich and successful peoples of every period have always believed that their solutions were universal, and up till the present day they try to sell them to or impose them on others to whom the solutions do not apply.

\section{Goals of business leaders from different societies}

A classroom experiment in my evening MBA class at the University of Hong Kong in 1995, repeated by colleagues in 15 other countries, showed striking differences in the goals that part-time MBA students, with day-time jobs, attributed to their own country's business leaders (Hofstede, Van Deusen, Mueller, Charles, \& the Business Goals Network, 2002; Hofstede, 2004). We used a list of 15 possible goals, developed in our Hong Kong class. In the overall average order of importance across the countries growth, continuity and this year's profits came on top. But MBA students from different countries deviated in different ways from this overall average. The relative ordering of goals within four of the countries (China, Denmark, India, and the USA.) is listed in Table 1.

Table 1 shows dramatic country differences. Four of India's top five goals are among Denmark's bottom five (family, continuity, wealth, and power). Three of Denmark's top five goals are among the bottom five in the USA (creating something new, profits 10 years from now, and responsibility towards employees). Respecting ethical norms comes top in China but among the bottom five in India. Short term (this year's) profits are among the top five in the USA only, and among the bottom five in China. The table reads like a recipe for conflict in globalization projects in which top management from one country tries to run businesses in another.

\section{What is Asian management?}

The key challenge for APJM and the Asia Academy of Management has been and still is to make Asia-based contributions to the state of the art in global management 
Table 1 Five relatively most and five relatively least important perceived goals (out of 15) ascribed to successful business leaders in four countries.

\begin{tabular}{|c|c|c|c|}
\hline China (1999) & India (1999) & Denmark (2004) & USA (1999) \\
\hline Most important & Most important & Most important & Most important \\
\hline $\begin{array}{l}\text { Respecting ethical } \\
\text { norms }\end{array}$ & Family interests & Creating something new & Growth of the business \\
\hline $\begin{array}{l}\text { Patriotism, national } \\
\text { pride }\end{array}$ & Continuity of the business & Profits 10 years from now & Personal wealth \\
\hline Power & Personal wealth & Honor, face, reputation & This year's profits \\
\hline $\begin{array}{c}\text { Honor, face, } \\
\text { reputation }\end{array}$ & Patriotism, national pride & Staying within the law & Power \\
\hline $\begin{array}{l}\text { Responsibility tds } \\
\text { society }\end{array}$ & Power & $\begin{array}{l}\text { Responsibility tds } \\
\text { employees }\end{array}$ & Staying within the law \\
\hline Least important & Least important & Least important & Least important \\
\hline $\begin{array}{l}\text { Creating something } \\
\text { new }\end{array}$ & Staying within the law & Family interests & Profits 10 years from now \\
\hline $\begin{array}{l}\text { Game and } \\
\text { gambling spirit }\end{array}$ & Creating something new & Power & $\begin{array}{l}\text { Responsibility tds } \\
\text { employees }\end{array}$ \\
\hline This year's profits & $\begin{array}{l}\text { Responsibility tds } \\
\text { employees }\end{array}$ & $\begin{array}{l}\text { Responsibility tds } \\
\text { society }\end{array}$ & Family interests \\
\hline Personal wealth & Respecting ethical norms & Personal wealth & Continuity of the business \\
\hline $\begin{array}{l}\text { Staying within the } \\
\text { law }\end{array}$ & $\begin{array}{l}\text { Game and gambling } \\
\text { spirit }\end{array}$ & $\begin{array}{l}\text { Continuity of the } \\
\text { business }\end{array}$ & Creating something new \\
\hline
\end{tabular}

[Source] Based on research by Hofstede et al. (2002), after adding 2004 data from Denmark collected by Mikael Søndergaard. Chinese data are from respondents studying in Australia and the USA but referring to mainland Chinese business leaders.

research (Peng, 2007). Meyer (2006) signaled that "Asian management research appears trapped between the apparently contradictory objectives of local relevance and international publication." Asian management scholars are still overwhelmingly trained in the USA, and their work has to meet US standards if they want to publish in international journals that really are US journals. This is a belated effect of one rich and successful society believing that its solutions are universal and selling them to the rest of the world. But we have entered an era in which ownership of global businesses has spread wider than ever before, and this will in due time undoubtedly change the market for management know-how as well.

If management is not universal, what is specific for Asian management? We have to be careful in categorizing. Asia is not at all a homogeneous entity-it is as heterogeneous as what is called the "West." The term "Western" management usually means US management. What French or Danish or British or Australian authors write about management in their own society does not necessarily follow American models. Within Asia, management is a very different process depending whether we focus on China, India, Japan, or Iran, and sometimes we cannot even generalize across different provinces within the same country. Are there any overall qualifications that apply to Asian as opposed to Western management?

My own classification of national cultures used first four, now five dimensions (Hofstede, 1980, 2001). The most evident difference between Asian countries on the one side and Western European and Anglo countries on the other relates to the dimension of Individualism versus Collectivism. Individualism stands for a society in 
which the ties between individuals are loose: everyone is expected to look after him/ herself and his/her immediate family only. Collectivism stands for a society in which people from birth onwards are integrated into strong, cohesive in-groups, which throughout their lifetime continue to protect them, in exchange for unquestioning loyalty. Western countries all scored above average on individualism, with the USA and Australia as the most individualist and Israel and Spain relatively least. Asian countries all scored below average on Individualism - that is, they scored collectivist - with China, Indonesia, Korea, and Pakistan relatively more and India, Japan, Iran, and the Arab countries relatively less collectivist. The in-group to which people relate in most cases is the extended family, but in Japan the employer fulfills part of the in-group role.

Worldwide there is a relationship between economic affluence and cultural Individualism. Not only do wealthier countries score relatively more individualist, but countries that became wealthier also became more individualist, a process we have observed in recent years in economically successful countries of Asia such as Japan, Korea, and Thailand. Old people, for example, are now less automatically taken care of by their families than they used to be. Nevertheless, while affluence thus increases Individualism, it does not make Asian countries as individualist as Western countries. Western countries already were more individualist when they still were quite poor themselves. So increasing affluence will reduce but not eliminate the difference between Asia and the West in this respect.

The Collectivism versus Individualism distinction has profound implications for the kind of management that is appropriate within a culture. The concept of "management" itself was developed in Britain and the USA in the nineteenth century, two countries already quite individualist in those days, and all theories of management that were subsequently developed portray their individualist roots. They are based on assumptions about the behavior of detached individuals. I know of no theories that deal with the role of family or ethnic loyalties in management and organization, and this lack represents a challenge for APJM and the Asia Academy of Management (Ahlstrom, Young, Chan, \& Bruton, 2004; Peng \& Jiang, 2006; Yeung, 2006).

A second dimension on which Asian and Western cultures are opposed, although not as strongly as on Individualism versus Collectivism, is Power Distance (large versus small). Power Distance is the extent of inequality in a society: I defined it as the extent to which the less powerful members of institutions and organizations within a country expect and accept that power is distributed unequally. I found Asian cultures to score relatively high on Power Distance, with Malaysia, Philippines, and Indonesia higher and Japan, Pakistan, Taiwan, and Iran in the middle of the scale. Among Western countries, the Latin countries (France, Belgium, Spain, and Italy) score high to medium and the others medium to low. Power Distance norms are transferred in parent-child relationships: they determine the role of respect for authority in organizations. Large Power Distance cultures can also be called respect cultures. Economic affluence relates inversely to levels of Power Distance, but the relationship is not as strong as to Individualism. With increasing affluence, power holders more and more need to justify themselves, as we have seen happening in countries like Korea and Indonesia. This represents democratization, but there is not one single way to democratize: the Latin countries in Europe also have become democracies while maintaining the "respect" element in their cultures. So I expect that Asian cultures with increasing affluence will democratize, but 
according to their own respect logic. Again, a role for APJM and the Asia Academy of Management will be to fill this gap and to study excellent management in the context of Asian respect relations (Chia et al., 2007). This includes the role of side payments, because more people in respect cultures hold uncontrolled power, there is more temptation in these cultures to use official power for unofficial personal gain (Lee \& Oh, 2007).

On two other dimensions, Uncertainty Avoidance and Masculinity versus Femininity, I found Asian countries to differ just as much among one another as Western countries.

The fifth dimension owes its discovery to Asian minds. In the early 1980 s, I met Professor Michael Bond of the Chinese University of Hong Kong. We discussed to what extent the results of cross-cultural research are influenced by the values not of the respondents, but of researchers like ourselves. As at that time nearly all researchers including us were Western, this might mean that questions specifically relevant to Asian minds might not even have been asked. Bond found a creative solution to this Western bias problem. He asked his Chinese colleagues to design a questionnaire with a deliberate Chinese culture bias, which he called the Chinese Value Survey (CVS) (Chinese Culture Connection, 1987). The CVS was translated from Chinese into English and other languages, and administered to female and male students in 23 countries around the world.

Statistical analysis of the results found dimensions of values significantly correlating with Individualism-Collectivism, Power Distance, and MasculinityFemininity, but also a new dimension which Western questionnaires so far had not revealed. Michael Bond called it Confucian Work Dynamism because both at the positive and at the negative pole it reminded of teachings of Confucius: it opposed future-oriented, dynamic Confucian values to present and past-oriented, static Confucian values. As the dimension was based on the answers of students in a large number of countries, most of whom had never heard of Confucius, I re-named it Long Term versus Short Term Orientation (Hofstede \& Bond, 1988).

Long Term Orientation means valuing, for example, persistence and thrift. Short Term Orientation pole means valuing "face" and respect for tradition. This dimension opposed many Asian countries to the rest of the world, in the sense that the Asian countries scored long-term and the others medium or short-term. The top long-term scorers were China, Hong Kong, Taiwan, Japan, and Korea. They were followed by Brazil but then again by Asian countries: India, Thailand, and Bangladesh. Asian countries on the short term side were the Philippines and Pakistan. No Western countries scored more than medium-term; the USA, Britain, and Canada scored short-term, as did the countries of Africa. Scores on the dimension were strongly correlated with the countries' economic success in the period 1970-2000 (Hofstede \& Hofstede, 2005: 223). Countries scoring long-term, in which the students said they valued thrift, in fact did have higher savings rates than countries scoring short-term (Read, 1993). More savings meant more money for productive investment. The management implications of this new dimension are again a promising focus for APJM and the Asia Academy of Management.

The story of the Chinese Value Survey leading to the discovery of the fifth dimension is an illustration of the importance of eliminating ethnocentric bias. Another, more recent, example is found in the area of personality research. A number of newer and older findings by Asian and European researchers suggest the 
need for expanding the dominant five-factor model of personality traits, known as the "Big Five," with a sixth factor, Dependence on Others, in order to keep the model culturally universal (Hofstede, 2007).

These examples show that researchers need their colleagues from other parts of the world to cross the cultural limits of their own thinking. For escaping from the cultural constraints in our own research, we therefore need to trade ideas across borders. Ultimately, studying Asian research, such as that published in APJM, will become as essential for Western colleagues as studying Western research is now for Asian scholars (Lau, 2002; Peng, 2005, 2007).

\section{Conclusion}

My viewpoint that management problems remain the same over time, but that their solutions differ from country to country is politically incorrect in an age in which business is supposed to be globalizing. Global business looks for global management solutions. But the diversity in business goals pictured in Table 1, and many stories of cultural clashes, suggest that businesses are and will remain less global than some people think they are, and less than their leaders would want them to be. Businesses have home countries, and these play an essential role in their effectiveness and their corporate identity (Carney, 2005). Supra-national organizations without a home country, like various UN agencies, are not known for their efficiency and effectiveness.

More and more Asian countries are becoming the home of new global corporations (Collinson \& Rugman, 2007; Mathews, 2006). Japan and Korea led the way, but their corporations mostly grew by "greenfield" expansion-founding their own subsidiaries, which mitigates culture clashes. Now, Chinese and Indian giants expand through acquisitions in Western countries, a much riskier strategy. Former culture clashes between the West and the East are reversed, and Asian managers will need cultural awareness training to understand their European and American subordinates (Tung, 2005). This direction suggests another new focus for $A P J M$ and the Asia Academy of Management.

\section{References}

Ahlstrom, D., Young, M. N., Chan, E., \& Bruton, G. 2004. Facing constraints to growth? Overseas Chinese entrepreneurs and traditional business practices in East Asia. Asia Pacific Journal of Management, 21: 263-285.

Carney, M. 2005. Globalization and the renewal of Asian business networks. Asia Pacific Journal of Management, 22: 337-354.

Cao, X. Q. 1980. The story of the stone (also known as The dream of the red chamber). Volume 3: The warning voice. Translated by D. Hawkes. Harmondsworth, Middlesex: Penguin Books [Original Chinese version published 1760].

Chia, H.-B., Egri, C., Ralston, D., Fu, P. P., Kuo, M. C., Lee, C., Li, Y., \& Moon, Y. 2007. Four tigers and a dragon: Values differences, similarities, and consensus. Asia Pacific Journal of Management, 24 (in press).

Chinese Culture Connection (a team of 24 researchers). 1987. Chinese values and the search for culturefree dimensions of culture. Journal of Cross-Cultural Psychology, 18: 143-164.

Collinson, S., \& Rugman, A. M. 2007. The regional character of Asian multinational enterprises. Asia Pacific Journal of Management, 24 (in press). 
d'Iribarne, P. 1989. La logique de l' honneur: Gestion des entreprises et traditions nationales. Paris: Seuil. Hofstede, G. 1980. Culture's consequences: International differences in work-related values. Beverly Hills, CA: Sage.

Hofstede, G. 1984a. Cultural dimensions in management and planning. Asia Pacific Journal of Management, 1: 81-99.

Hofstede, G. 1984b. National cultures revisited. Asia Pacific Journal of Management, 2: 22-28.

Hofstede, G. 1999. The universal and the specific in 21st-century global management. Organizational Dynamics, 28(1): 34-43.

Hofstede, G. 2001. Culture's consequences: Comparing values, behaviors, institutions, and organizations across nations, 2nd ed. Thousand Oaks, CA: Sage.

Hofstede, G. 2004. Business goals and corporate governance. Asia Pacific Business Review, 10: $292-301$.

Hofstede, G. 2007. A European in Asia. Asian Journal of Social Psychology, 10 (in press).

Hofstede, G., \& Bond, M. H. 1988. The Confucius connection: From cultural roots to economic growth. Organizational Dynamics, 16(4): 4-21.

Hofstede, G., \& Hofstede, G. J. 2005. Cultures and organizations: Software of the mind, 2nd ed. New York: McGraw-Hill.

Hofstede, G., Van Deusen, C. A., Mueller, C. B., Charles, T. A., \& the Business Goals Network. 2002. What goals do business leaders pursue? A study in fifteen countries. Journal of International Business Studies, 33: 785-803.

Lau, C.-M. 2002. Asian management research: Frontiers and challenges. Asia Pacific Journal of Management, 19: 171-178.

Lee, S.-H., \& Oh, K. 2007. Corruption in Asia: Pervasiveness and arbitrariness. Asia Pacific Journal of Management, 24(1): 97-114.

Mathews, J. A. 2006. Dragon multinationals: New players in 21st century globalization. Asia Pacific Journal of Management, 23: 5-28.

Meyer, K. E. 2006. Asian management research needs more self-confidence. Asia Pacific Journal of Management, 23: 119-137.

Moore, K., \& Lewis, D. 1999. Birth of the multinational: Two thousand years of ancient business history, from Ashur to Augustus. Copenhagen, Denmark: Copenhagen Business School Press.

Peng, M. W. 2005. From China strategy to global strategy. Asia Pacific Journal of Management, 22: 123141.

Peng, M. W. 2007. Globalizing the Asia Pacific Journal of Management. Asia Pacific Journal of Management, 24(1): 1-7.

Peng, M. W., \& Jiang, Y. 2006. Family ownership and control in large corporations in Asia: The good, the bad, the irrelevant. William Davidson Institute Working Paper 840, University of Michigan (accessible from http://www.ssrn.com).

Read, R. 1993. Politics and policies of national economic growth. Unpublished PhD dissertation, Stanford University.

Tolstoy, L. 1978. Anna Karenin. Translated by R. Edmonds. Harmondsworth, Middlesex: Penguin Books [Original Russian version published 1878].

Tung, R. L. 2005. New era, new realities: Musings on a new research agenda . . . from an old timer. Asia Pacific Journal of Management, 22: 143-157.

Yeung, H. W. 2006. Change and continuity in Southeast Asian ethnic Chinese business. Asia Pacific Journal of Management, 23: 229-254.

Geert Hofstede (PhD, University of Groningen) is a Professor Emeritus of the University of Maastricht, The Netherlands. Since the publication of his book Culture's Consequences $(1980,2001)$, he has been a pioneer of comparative intercultural research; his ideas are used worldwide. A student-level book Cultures and Organizations: Software of the Mind (1991, new edition 2005 with Gert Jan Hofstede) has so far appeared in 17 languages. He is one of the most cited European authors in the Social Sciences Citation Index. $\mathrm{He}$ is a Doctor Honoris Causa of four European Universities, a Honorary Fellow of the International Association for Cross-Cultural Psychology, and a Fellow of the Academy of Management as well as of the Center for Economic Research at the University of Tilburg. This is Professor Hofstede's third contribution to APJM after Hofstede (1984a, 1984b). His website is www.geerthofstede.nl 